\title{
Taxonomy, diversity and diagnosis of Tetrahymenosis, and its recent identification measures in aquaculture inferred from infections in Northeastern China
}

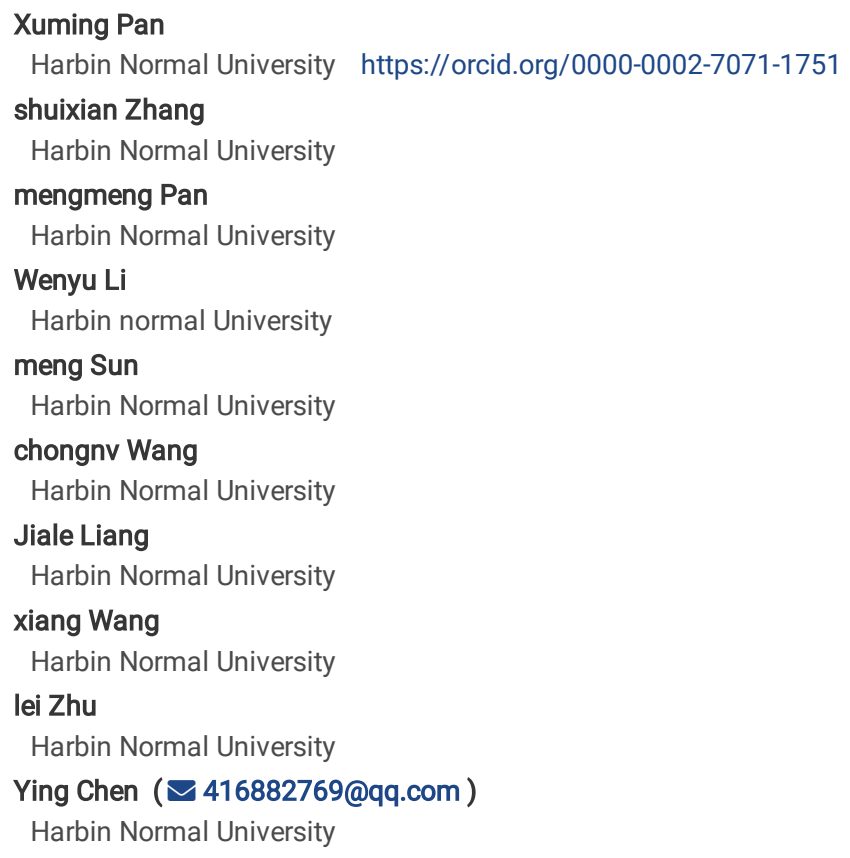

\section{Short report}

Keywords: Tetrahymenosis, facultative parasitic ciliates, Simultaneous fluorescence in situ hybridization, diversity, histopathology

Posted Date: March 4th, 2020

DOI: https://doi.org/10.21203/rs.3.rs-15239/v1

License: (c) (1) This work is licensed under a Creative Commons Attribution 4.0 International License. Read Full License 


\section{Abstract}

Background Tetrahymenosis caused by about ten parasitic Tetrahymena species belonging to the Phylum Ciliophora has been recognized as an emerging problem inflicting significant economic loss in aquaculture industry in the world. Increasing knowledge and identification of Tetrahymenosis are important.

Methods Four parasitic Tetrahymena species were collected from eight commercially farmed fishes in Harbin, northeastern China. Specific oligonucleotide probe and fluorescence in situ hybridization staining was designed and tested. Hoechst33342 staining methods, gene sequencing and phylogenetic analyses were also conducted.

Results Tetrahymena pyriformis, T. vorax, T. chironomi and T. bergeri are the four species responsible for Tetrahymenosis in various fishes in Harbin. Taxonomy, diagnosis, diversity, pathogenicity, and histopathology of Tetrahymenosis were supplemented, analyzed and summaried, based on the present and previous work. The term Tetrahymenosis is diagnosised as diseases affecting a number of fishes, crustaceans, mollus, beetle, dragonfly, salmon, slug, midge larvae and freshwater mussel species that caused by ciliates of the genus Tetrahymena which constitutes an abundant group inhabit various aquaculture and natural habitats. Improved classification of parasitic Tetrahymena was provided. Phylogeny of parasitic Tetrahymena species was studied, and an SSU-rDNA targeted oligonucleotide probe labeled with a fluorochrome was designed, and the FISH protocol was optimized for identification of Tetrahymena species,

Conclusions The manifestations of histopathology in fish typically include lesions on the body surface, and affected organs include the skin, musculature, viscera, eye socket and spinal cord; masses of ciliates can be detected in copious amount of mucus and between spaces in the damaged tissues. Improved classification of parasitic Tetrahymena is provided: facultatively parasitic forms ( T. pyriformis, T. rostrate, T. bergeri and T. vorax ), facultatively free-living forms ( T. chironomi , T. corlissi, T. rotunda, T. glochidiophila and T. papula ) and parasitic forms ( T. stegomyiae and T. limacis ).The phylogenic results indicate that Tetrahymena spp. belonging to 'borealis' group have a greater probability to become parasitism. the method of which can be used for quick and early detection of Tetrahymenosis.

\section{Background}

Tetrahymena, assigned to class Oligohymenophorea and family Tetrahymenidae, is a pyriform-shaped ciliate, with buccal cavity equipped with one paroral membrane and three serially arranged membranelles [1-15]. Occasionally, this microorganism can become parasitic and affect a wide range of hosts, including ornamental fish, edible fish, beetle, dragonfly, salmon, slug, midge larvae and freshwater mussel [16-21]. Pathogenic characteristics of infected fishes by Tetrahymena spp. are similar: possessing typical whitish lesions on the body surface, and affected organs include the skin, musculature, viscera, eye socket and spinal cord; masses of ciliates can be detected in copious amount of mucus and between spaces in the damaged tissues [16-18, 22]. Some of them are facultative parasites while others might be obligate parasites [5]. The most pathogenic species of this genus, according to published literature, is T. corlissi, which often leads to a systemic infection and well-known as "guppy killer disease" [23-25]. They are responsible for serious economic losses in commercial fish farms around the world.

While morphological method is the routine way to identify Tetrahymena spp., it has the limitations as follows: 1) the commonly used silver staining methods for reliable identification need considerable experience and staining failure is often the case, making species identification difficult, 2) parasitic Tetrahymena species are hard to control when massive infection occurs. Thus, early detection, quantification, and control of these infectious pathogens are important in aquaculture [1, 26]. FISH with specific fluorochrome-labeled oligonucleotide probes is a staining technique that allows molecular identification of targeted organisms in mixed assemblages by means of a fluorescence microscopy, this method can overcome the drawbacks of the morphological method and yield prompt detection, and has been applied successfully to pathogenic ciliates (e. g. Pseudocohnilembus persalinus, Boveria labialis and B. subcylindrica) [2730]. However, to date, there are no general fluorochrome-labeled oligonucleotide probes for parasitic Tetrahymena spp.

\section{Methods}

Ciliates isolation, cultivation and morphological identification.

Tetrahymena pyriformis, T. vorax, T. chironomi and T. bergeri were collected from commercially farmed fishes e. g. Malapterurus electricus, Tetraodon palembangensis, Poecilia latipinna, Channa aurantimaculata, Carassius auratus, zebrafish, Phoxinus lagowskii, Pelteobagrus fulvidrac, from fish farms or markets in Harbin, northeastern China between September 2017 and November 2019. Mucus or tissue were spread on glass slides using glass slides and the fresh mounts examined under a light microscope (20X and 40X objective) to confirm infection. Slides containing ciliates were selected for silver staining and morphological description. Cells were cultured at $25^{\circ} \mathrm{C}$ and maintained in a culture medium (sterilized distilled water boiled with fish meat, stored at $-20{ }^{\circ} \mathrm{C}$ ). Live observations were made under a microscope with phase-contrast illumination. Silver carbonate [31] and protargol [32] staining methods were used to reveal the infraciliature. All measurements of stained specimens were made under oil immersion $(1250 \mathrm{x})$.

Design and test of the specific oligonucleotide probe and FISH staining.

Probe (nucleotides, 19 ; GC contents, $47.37 \%$; nucleotide-nucleotide $\mathrm{Tm}, 53.1^{\circ} \mathrm{C}$ ) was designed using the probe design tool as implemented in the ARB software package for the SSU-rDNA sequence of the present Tetrahymena pyriformis, T. vorax, T. chironomi and T. bergeri, and other Tetrahymena species from GenBank [30]. Generated probes were checked against the GenBank sequence collection by a standard nucleotide-nucleotide BLAST search [33]. FISH was used to visualize Tetrahymena spp. above both in field samples and a mixture of species as well as Pseudocohnilembus persalinus and Uronema marinum that frequently occurred in the same hosts as the negative controls. Cells were fixed with $50 \%$ Bouin's solution and filtered onto a 2 - $\mu \mathrm{m}$-pore-size cellulose nitrate membrane ( $25 \mathrm{~mm}$ in diameter) using low under pressure. The membrane was then washed five times with $2 \mathrm{ml}$ of filtered sterile water. The basic hybridization followed the protocol of Stoeck et al. (2003) and Zhan et al. (2014). 
Hoechst33342 staining methods.

Cells of parasitic Tetrahymena species were stained and fixed in 4\% PFA for 20 min at room temperature, then were washed with PBS for 5 min at room temperature. Cells were then incubated with Hoechst $33342(100 \mathrm{ng} / \mathrm{mL}$ in PBS) in the dark for 15 min at room temperature, then cells were washed with PBS for $5 \mathrm{~min}$ at room temperature. At last, cells were viewed using a fluorescence microscope with emission $350 \mathrm{~nm}$ and a blue/cyan emission filter (460 $\mathrm{nm}$ ) (Fig. 3) [34].

Gene sequencing and Phylogenetic analyses.

Single cells of Tetrahymena pyriformis, T. vorax, T. chironomi and T. bergeri were washed individually with distilled water. Genomic DNA was extracted from five cells using a DNeasy Blood \& Tissue Kit (Qiagen, Hilden, Germany), following the manufacturer's instructions. The SSU rRNA gene was amplified with the primers 82F- (5'-GAA ACT GCG AAT GGC TC-3') and 18 s-R (5'-TGA TCC TTC TGC AGG TTC ACC TAC-3') [35]. Bidirectional sequencing was performed by the Shanghai Sunny Biotechnology Company (Shanghai, China). The SSU rRNA gene sequences of T. pyriformis, T. vorax, T. chironomi and T. bergeri were aligned with sequences of other related taxa on the European Bioinformatics Institute web server (URL: http://www.ebi.ac.uk/Tools/msa/muscle/) using the MUSCLE package. Resulting alignments were refined by trimming both ends using BioEdit 7.0.5.2 [36]. Bayesian inference (BI) analysis was carried out with MrBayes on XSEDE v3.2.6 (Ronquist and Huelsenbeck 2003) on CIPRES Science Gateway [37] using the GTR + I + G evolutionary model as the best-fit model selected by MrModeltest v.2 [38] according to the Akaike Information Criterion (AIC). A Maximum Likelihood (ML) tree was constructed using RAxML-HPC2 v. 8.2.10 [39] on the CIPRES Science Gateway with the optimal model GTR $+I+G$ evolutionary model as the best model according to the AIC criterion selected by the program Modeltest v.3.4 [40]. Node support came from 1000 bootstrap replicates. TreeView v.1.6.6 [41] and MEGA v5 were used to visualize tree topologies.

\section{Results}

\section{Taxonomy}

The term Tetrahymenosis covers diseases affecting a number of fishes, crustaceans, mollus, beetle, dragonfly, salmon, slug, midge larvae and freshwater mussel species that caused by ciliates of the genus Tetrahymena which constitutes an abundant group inhabit various aquaculture and natural habitats (Table 1). Tetrahymena belongs to the phylum Ciliophora, Class Oligohymenophorea, order Tetrahymenida and family Tetrahymenidae [4]. Currently, the genus Tetrahymena Furgason, 1940 (Ciliophora, Hymenostomatida) is comprised of over 40 species [2-5, 13, 19]. Tetrahymena is generally pyriform-shaped, uniformly covered with meridional kineties, the buccal cavity is equipped with one curved undulating membrane with paired basal bodies organized in zigzag pattern (i.e. stichodyad), located on right edge of the buccal cavity, and three parallel membranelles. Within species, size variations depend on culture medium, physiological state and life stage (Corliss, 1973). The life cycle of Tetrahymena species is typified by the following developmental stages: theront, trophont, tomont and tomite.

\section{Diversity of parasitic Tetrahymena}

Tetrahymena species commonly exhibits a whole range of existence from the completely free-living state through stages of facultative parasitism to obligate endoparasitism [6]. Corliss (1971a) classified Tetrahymena parasitism into three types: facultatively parasitic forms (generally found free-living in nature but for which a parasitic existence is not uncommon), facultatively free-living forms (typically found in association with a host but capable in nature as well as experimentally) and parasitic forms (as endoparasites associated with specific hosts). To date, about ten Tetrahymena species (T. corlissi, T. pyriformis, T. stegomyiae, T. chironomi, T. vorax, T. rostrata, T. limacis, T. rotunda, T. glochidiophila and T. papula; Table 1) have been generally reported as pathogenicity to various invertebrates and vertebrates $[16-18,22]$.

In the current work, T. pyriformis, T. vorax, T. chironomi and T. bergeri are the four species isolated from fish farms or markets in Harbin. The cells commonly showed a high densities and vitalities when just isolated from the various fishes (Figs 1,2). The detailed morphology of the four species are reported before, and the Harbin populations of the four species are similar with those previous descriptions (Figure 2) [1, 3, 7, 42]. The topologies of BI trees are similar to that of $\mathrm{ML}$ trees, so only the ML trees are shown in Figure 4 with branch support values for both analyses. In the consensus topology, all the parasitic Tetrahymena spp. (Table 1) having sequence data are selected to constructed trees. As is shown, all the parasitic forms cluster in the 'borealis' group. The clustering pattern indicates that "borealis" Tetrahymena spp. might have a greater probability to become parasitism [13, 43]. In addition, Harbin population of T. pyriformis, $T$. vorax, and T. bergeri cluster with their previous populations, respectively, which also supports the morphological identifications.

\section{Diagnostic features:}

\section{Pathogenicity/Histopathology.}

As pathogenic parasites, histopathology of parasitic Tetrahymena spp. have been studied in detail and reported many times [16, 18, 22, 44-48]: possessing typical whitish lesions on the body surface, and affected organs include the skin, musculature, viscera, eye socket and spinal cord; masses of ciliates can be detected in copious amount of mucus and between spaces in the damaged tissues. In fishes, extensive studies reporting the organ-specific pathological changes when infected with Tetrahymenosis are available, and typical gross lesions of Tetrahymena infection are characterized by protrusion of scales, swelling, ulcerative wounds on the skin, blindness, and protrusion of eyes $[47,48,22,18]$. In our recent study, four Tetrahymena species were isolated Malapterurus electricus, Tetraodon palembangensis, Poecilia latipinna, Channa aurantimaculata, Carassius auratus, zebrafish, Phoxinus lagowskii, 
Pelteobagrus fulvidrac from farms in Harbin. At arrival, fish did not have any apparent gross signs of Tetrahymena infection. Nonetheless, the parasite was observed in fresh-mount preparations on the skin, in the gills and in internal organs (Figure 2). Noticeable, many cells of Tetrahymena bergeri were observed in the skin mucus of Phoxinus lagowskii, individuals of $P$. lagowskii exhibited symptoms that no feeding, staying upside down, gasping attack edges and secreting a lot of mucus (Figure 3G, H, arrowhead). Tetrahymena pyriformis were observed from guts of diseased zebrafish (Figure 3F, arrowhead). Pelteobagrus fulvidraco had many large, round deep skin lesions all over the body with hyperaemic margins exposing the skeletal muscle, and scrapings revealed the presence of $T$. vorax (Figure $2 \mathrm{G}$, arrowheads). Gills of all diseased fish were shriveling, dark and anaemic, gills of several fish had dark-red ulceration (Figure 2l; arrowhead). Some cells of $T$. vorax were also detected in gaps among the gill filaments.

Skin lesions or mucus of fishes were directly stained in vivo by Hoechst33342 staining method, and Figure $3 \mathrm{~A}-\mathrm{C}$ show the process of facultatively parasitic Tetrahymena sp. eating bacteria around the cell (Figure 3B), and Tetrahymena sp. eating tissues (skin or gill) as well as bacteria of host (Figure 3C). Cytoplasm of Tetrahymena sp. always contain many (approximately $2-5 \mu \mathrm{m}$ in diameter) bacteria-or fish tissue- filled food vacuoles and variable-sized granules, distributed randomly (Figure 3C, arrowhead). The result indicates that facultatively parasitic Tetrahymena sp. can physically devour tissue, not only by producing enzyme [49].

\section{Detection and identification using FISH}

The probe Tetr2020 evaluated with the probe match tool of the ARB software package and the GenBank BLAST tool showed that they are specific to Tetrahymena spp. The probe Tetr2020 (5'-TGTAGTAGCCGTTTCTCAG-3') had at least two mismatches to other closely related species like Uronema spp., Pseudocohnilembus spp. and Cyclidium spp. FISH with the probes Tetr2020 resulted in the presence of a red fluorescence signal each for T. pyriformis, T. vorax, T. chironomi and T. bergeri (Figure 3D, E), clearly distinguishable from the faint autofluorescence signal achieved with negative-control hybridizations using the Tetr2020 probe to hybridize the untargeted ciliates Pseudocohnilembus persalinus, Uronema marinum and isolated from the same hosts (Figure 3F). Thus, the probes Tetr2020 is also a general probe suitable for widely and rapidly detecting Tetrahymenosis.

\section{Discussion}

Corliss (1971a) classified Tetrahymena parasitism into facultatively parasitic forms ( T. pyriformis and T. rostrata), facultatively free-living forms ( $T$. chironomi and T. corlissi) and parasitic forms (T. stegomyiae and T. limacis). However, based on later and the present works (Tables 1, 2), supplementary classification is as follows: facultatively parasitic forms (T. pyriformis, T. rostrate, T. bergeri and T. vorax), facultatively free-living forms (T. chironomi, T. corlissi, T. rotunda, T. glochidiophila and T. papula) and parasitic forms (T. stegomyiae and T. limacis). and the morphology of pathogens and the hosts and data sources are compared in Tables 1 and 2. Tetrahymena bergeri is reported in the present work as facultatively parasitic forms in Channa aurantimaculata for the first time (free-living reported before), the reason possibly is that high latitude cold areas may have multiple life-styles when cold weather, due to the slow degradations of microorganisms and insufficiency of food [50]. Except for the ten species showed above, many unidentified Tetrahymena sp. conducted infections were also recorded, e. g. Stolk (1960) isolated Tetrahymena sp. from the central nervous system of larvae of Cyprinous carpio, Abramis brama and Ameiurus sp., Kim et al., (2002) examined the fish imported from Southeast Asian countries into Korea and reported of infection from the consignment of ornamental fish, Laoprasert et al., (2001) reported of tetrahymenosis in guppies from local fish farms, appearing as a white ulcerative disease. Thilakaratne et al., (2003) reported of Tetrahymena sp. infection in guppies from commercial ornamental fish farms in Sri Lanka, along with other parasites in different ornamental fish species. Pimenta-Leibowitz et al., (2005) reported that poor environmental and adverse physiological conditions pre-dispose to infections with Tetrahymena sp.

As a histophagous parasite, Tetrahymena disintegrates host tissue and feeds on cell debris. Infection is showed by whitish patches due to the masses of ciliates in copious amount of mucus, patches usually located on the dorso-lateral skin around the abdomen (Johnson, 1978). Typical gross lesions of Tetrahymena infection are characterized by protrusion of scales, swelling, ulcerative wounds on the skin, blindness, and protrusion of eyes (Johnson, 1978). Numerous Tetrahymena spp. may form a rim around the eye orbit (spectacled eye). The parasites route of entry into the body has not been reported. In histopathological analyses, the ciliates were found to be distributed between spaces in the damaged tissues, and extensive necrotic changes occur in the muscle and subdermal tissue. Necrosis of the epithelial cells, extending to the musculature, and disfigured dermal and subcutaneous tissue with edema and hemorrhage was also reported $[24,51]$.

Compared with Scuticociliatosis, Tetrahymenosis can be found in a more wide-ranging hosts (e. g. slugs, hick embryos, dragonfly, helgramite, roach, cockroach and caterpillar), and Tetrahymenosis is easier to discovered in freshwater fish (vs. mostly in marine habitat fishes for Scuticociliatosis) (24, 46, 48 , 52). However, their major clinico-pathological manifestations are similar: anemia, weight loss, dark coloration, enteritis, excessive body mucus, yellowish intestinal mucus, loss of scales, hemorrhagic and/or bleached spots on the skin, and dermal necrotic lesions that finally destroy tissues lead to high mortalities $[8,16,50,52]$.

As a test case using probes for the identification of pathogenic ciliates in aquaculture, the present study utilized the probe Tetr2020 to unambiguously detect Tetrahymenosis (Figure 3, D). The general identification by strong fluorescence signals from the oligonucleotide probe can be used for quick and early detection of Tetrahymenosis infections on both invertebrates and vertebrates, especially fish. The FISH probe designed here has the potential to be used for confirming the geographical distribution of parasitic Tetrahymena spp. and detecting the possible dispersal of this facultative pathogen [27-30]. The FISH approach also provided some morphological information such as body shape, macro and micronuclei shape and number of micronuclei of parasitic Tetrahymena spp.

\section{Conclusions}


The manifestations of histopathology in fish typically include lesions on the body surface, and affected organs include the skin, musculature, viscera, eye socket and spinal cord; masses of ciliates can be detected in copious amount of mucus and between spaces in the damaged tissues. Improved classification of parasitic Tetrahymena is provided: facultatively parasitic forms (T. pyriformis, T. rostrate, T. bergeri and T. vorax), facultatively free-living forms (T. chironomi, T. corlissi, T. rotunda, T. glochidiophila and T. papula) and parasitic forms (T. stegomyiae and T. limacis). The phylogenic results indicate that Tetrahymena spp. belonging to 'borealis' group have a greater probability to become parasitism. the method of which can be used for quick and early detection of Tetrahymenosis.

\section{List Of Abbreviations}

Fluorescence in situ hybridization

FISH

\section{Declarations}

\section{Ethics approval and consent to participate}

Not applicable.

\section{Consent for publication Availability of data and materials}

The datasets supporting the conclusions of this article are included within the article. Representative sequences are submitted to the GenBank database (accession numbers are provided in Figure 4).

\section{Competing interests}

PXM and CY work at Harbin Normal University, Harbin, China. The study was conducted as part of a research program to investigate Tetrahymenosis in aquaculture in Northeastern China.

\section{Funding}

Natural Science Foundation of China (project numbers: 31970498), Heilongjiang Province Science Foundation for Youths (project number: Qc2017017).

\section{Authors' contributions}

The study design, protocol and were prepared by ZSX, PMM, LWY, SM, WCN, LJL, WX and ZL, and report of the study and reviewed by PXM and CY. PXM and his team at Harbin Normal University were responsible for the animal phase and data collection. PXM were responsible for compiling the first draft of the manuscript. All authors revised and approved the final version.

\section{Acknowledgements}

This work was supported by the Natural Science Foundation of China (project numbers: 31970498), Heilongjiang Province Science Foundation for Youths (project number: QC2017017).

\section{References}

1. Corliss JO. Tetrahymena chironomi nov., a ciliate from midge larvae, and the current status of facultative parasitism in the genus Tetrahymena. Parasitology. 1960;50:111-153.

2. Corliss JO. Facultative parasitism in Protozoa and its possible evolutionary significance. (Abstr.) Parasitology. 1962;52:

3. Corliss JO. Tetrahymena, a ciliate genus of unusual importance in modern biological research. Acta Protozool. 1965;3:1-

4. Corliss JO. The value of ontogenetic data in reconstructing protozoan phylogenies. Trans Amer Micros Soc. 1968;87:1-

5. Corliss JO. The comparative systematics of species comprising the hymenostome ciliate genus Tetrahymena. J Protozool. 1970;17:198-

6. Corliss JO. Thoughts on the evolutionary origin of endoparasitism. (Abstr.) Program and Abstracts, 46th Annual Meeting, American Society of Parasitologists, Los Angeles, 23-27 Aug., 1971a, p. 28.

7. Corliss J0. Type-specimens for the ten species of Tetrahymena (Protozoa: Ciliophora). Trans Amer Micros Soc. 1971b;90:243-252

8. Corliss JO. Tetrahymena and some thoughts on the evolutionary origin of endoparasitism. Trans Am Microsc 1972;566-573. 
9. Lynn DH, Doerder FP, Gillis PL, Prosser RS.

Tetrahymena glochidiophila sp., a new species of Tetrahymena (Ciliophora) that causes mortality to glochidia larvae of freshwater mussels (Bivalvia). Dis Aquat Organ. 2018;127:125-136.

10. Wang, YR, Wang Y., Sheng Y, Huang J, Chen X, Al-Rasheid KAS, Gao S. A comparative study of genome organization and epigenetic mechanisms in model ciliates, with an emphasis on Tetrahymena, Paramecium and Oxytricha. Eur J Protistol. 2017a;61:376-387.

11. Wang YY, Chen X, Sheng Y, Liu Y, Gao S. $\mathrm{N}^{6}$-adenine DNA methylation is associated with H2A. Z-containing well-positioned nucleosomes in Pol IItranscribed genes in Tetrahymena. Nuc Acid Res. 2017b;45:11594-

12. Wang YY, Sheng YL, Liu YQ, Pan B, Huang J, Warren A, Gao S. $N^{6}$-methyladenine DNA modification in the unicellular eukaryotic organism Tetrahymena thermophila. Eur J Protistol. 2017c;58:94-

13. Pan M, Wang R, Yin H, Pan X, Mu W, Khaled A, Fan X, Pan X. Redescription of a hymenostome ciliate, Tetrahymena setosa (Protozoa, Ciliophora) notes on its molecular phylogeny. J Eukaryot Microbiol. 2019;66:413-

14. Xu J, Bo T, Song W, Wang W. 2019a. Metabolomic fingerprint of the model ciliate, Tetrahymena thermophila determined by untargeted profiling using gas chromatography-mass spectrometry. J Ocean Univ China. 18:654-662.

15. Xu J, Li XX, Song WB, Wang W, Gao, S. Cyclin cyc2 is required for elongation of meiotic micronucleus in the unicellular eukaryotic model organism Tetrahymena thermophila. Sci China Life Sci. 2019b;62:668-

16. Thompson JC. Experimental infections of various animals with strains of the genus Tetrahymena. J Protozool. 1958;5:203-5.

17. Lom J. 1995. Thricodinidae and other ciliates (Phylum Ciliophora) 1: 229-262. In: Fish Diseases and Disorders. Woo, P.T.K. CABI Publishing. New York

18. Shenberg S. Histopathology of the ciliate Tetrahymena corlissi infection in guppy Poecilia reticulata. MSc thesis, The Hebrew University of Jerusalem, Jerusalem, Israel.

19. Simon EM, Nanney DL, Doerder FP. 2008. The "Tetrahymena pyriformis" complex of cryptic species. Biodivers Conserv. 2003;17:365-380.

20. Pimenta-Leibowitz M, Ariav R, Zilberg D. Environmental and physiological conditions affecting Tetrahymena infection in guppies, Poecilia reticulata Peters. J Fish Dis. 2005;28:539-547.

21. Prosser RS, Lynn DH, Salerno J, Bennett J, Gillis PL. The facultatively parasitic ciliated protozoan, Tetrahymena glochidiophila (Lynn, 2018), causes a reduction in viability of freshwater mussel glochidia. J Invertebr Pathol. 2018;157:25-

22. Lawhavinit O, Chukanhom K, Hatai K. Effect of Tetrahymena on the occurrence of achlyosis in the guppy Poecilia reticulata. Mycoscience. 2002;43:2731.

23. Ferguson HW, Hicks BD, Lynn DH, Ostland VE, Bailey J. Cranial ulceration in Atlantic Salmon Salmon salar associated with Tetrahymena Dis Aquat Organ. 1987;2: 191-195.

24. Imai S, Tsurimaki S, Goto E, Wakita K, Hatai K. Tetrahymena infections in guppies Poecilia reticulata. Fish Pathology. 2000;35:67-

25. Hatai K, Chukanhom K, Lawhavinit OA, Hanjavanit C, Kunitsune M, Imai S. Some biological characteristics of Tetrahymena corlissi isolated from guppy in Thailand. Fish Pathol.2001;36:195-

26. Stolk A. Galucoma in the central nervous system of the carp. Nature, 1960;184:1737.

27. Stoeck T, Taylor GT, Epstein SS. Novel eukaryotes from the permanently anoxic Cariaco Basin (Caribbean Sea). Appl Environ Microbiol. 2003;69:56565663.

28. Fried J, Foissner W. Differentiation of two very similar Glaucomid ciliate morphospecies (Ciliophora, Tetrahymenida) by fluorescence in situ hybridization with 18S rRNA targeted oligonucleotide probes. J Eukaryot Microbiol. 2007;54:381-387.

29. Zhan Z, Stoeck T, Dunthorn M, Xu K. Identification of the pathogenic ciliate Pseudocohnilembus persalinus (Oligohymenophorea: Scuticociliatia) by fluorescence in situ hybridization. Eur J Protistol. 2014;50:16-

30. Zhan Z, Li J, Xu K. Detection and quantification of two parasitic ciliates Boveria labialis and Boveria subcylindrica (Ciliophora: Scuticociliatia) by fluorescence in situ hybridization. J Eukaryot Microbiol.2018;65:440-

31. Foissner W. The silver carbonate methods. In: Protocols in protozoology (Eds. J. J. Lee and A. T. Soldo). Society of Protozoologists, Allen Press Inc. 1992; C7.1-7.3.

32. Wilbert N. Eine verbesserte Technik der Protargolimprägnation für Ciliaten. 1975;64:171-179.

33. Behrens S, Rühland C, Inácio J, Huber H, Fonseca Á, Spencer-Martins I, Fuchs BM, Amann R. In situ accessibility of small-subunit rRNA of members of the domains Bacteria, Archaea, and Eukarya to Cy3-labeled oligonucleotide probes. Appl Environ Microbiol. 2003;69:1748-758.

34. Crowley LC, Marfell BJ, Waterhouse NJ. Analyzing cell death by nuclear staining with Hoechst 33342. Cold Spring Harbor Protocols, pdb-prot087205. 2016.

35. Medlin L, Elwood HJ, Stickel S, Sogin ML. The characterization of enzymatically amplified eukaryotic 16S-like rRNA-coding regions. Gene. 1988;71:491499.

36. Hall TA. BioEdit: a user-friendly biological sequence alignment editor and analysis program for Windows 95/98/NT. Nucl Acids Symp Ser. 1999;41:95-98.

37. Miller M, Pfeiffer W, Schwartz T. 'Creating the CIPRES Science Gateway for inference of large phylogenetic trees' in Proceedings of the Gateway Computing Environments Workshop (GCE), 14 Nov. New Orleans, LA. p. 1-8; 2010.

38. Nylander JAA. MrModeltest v2. Distributed by the author. Department of Systematic Zoology, Evolutionary Biology Centre, Uppsala University; 2004.

39. Stamatakis A, Hoover P, Rougemont J. A rapid bootstrap algorithm for the RAxML web servers. Biol. 2008;57:758-771. 
40. Posada D, Crandall KA. Modeltest: testing the model of DNA substitution. Bioinformatics. 1998;14:817-818.

41. Page RDM. TREEVIEW: an application to view phylogenetic trees on personal computers. Comput Appl Biosci. 1996;12:357-358.

42. Roque M, De Puytorac P, Savoie A. Caractéristiques morphologiques et biologiques de Tetrahymena bergerinov., cilié hyménostome tetrahyménien. Protistc 351.

43. Chantangsi C, Lynn DH, Brandl MT, Cole JC, Hetrick N, Ikonomi P. Barcoding ciliates: a comprehensive study of 75 isolates of the genus Tetrahymena. Int J Syst Evol Micr. 2007;57:2412-

44. Goven BA, Dawe DL, Gratzek JJ. Protection of channel catfish, Ictalurus punctatus against Ichthyophthirius multifiliis Fouquet by immunisation with varying doses of Tetrahymena pyriformis (Lwoff) cilia. Aquaculture. 1981;23:269-273.

45. Lom J. Diseases caused by protistans/Diseases of marine animals/Diseases of marine animals. Ed. O. Kinne. - Hamburg: Biol Anst Helgoland. 1984;4:309-

46. Lom J, Dykova I. Protozoan parasites of fishes. Developments in Aquaculture and Fisheries Science 26. Elsevier, Amsterdam, p $253 ; 1992$.

47. Edgerton B, O'Donoghue P, Wingfield M, Owens L. Systemic infection of freshwater crayfish Cherax quadricarinatus by hymenostome ciliates of the Tetrahymena pyriformis Dis Aquat Organ. 1996;27:123-129.

48. Thilakaratne ID, Rajapaksha G, Hewakopara A, Rajapakse RP, Faizal AC. 2003. Parasitic infections in freshwater ornamental fish in Srilanka. Aquat. Organ. 31:157-62.

49. Al-Marzouk A, Azad IS. Growth kinetics, protease activity and histophagous capability of Uronema infesting cultured silver pomfret Pampus argenteus in Kuwait. Dis Aquat Organ. 2007;76:49-56.

50. Herbert B, Graham P. Tetrahymenosis, columnaris disease and motile aeromonad septicaemia in golden perch, Macquaria ambiqua (Richardson), from Australia. Diseases in Asian aquaculture VI. Fish Health Section, Asian Fisheries Society, Manila. 2008; 179-

51. Ponpornpisit A, Endo M, Murata H. Experimental infections of a ciliate Tetrahymena pyriformis on ornamental fishes. Fisheries Science. 2000;66:10261031.

52. Harikrishnan R, Balasundaram C, Heo MS. Scuticociliatosis and its recent prophylactic measures in aquaculture with special reference to South Korea taxonomy, diversity and diagnosis of scuticociliatosis: Part I Control strategies of scuticociliatosis: Part II. Fish Shellfish Immunol. 2010;29:15-31.

53. Dobrzanska J. Investigations on ciliates living in lamelli branchiates of small waterbodies. Bull Acad Polonaise Sci. 1958;6:113-

54. Hoffman GL, Landolt M, Camper JE, Coats DW, Stookey JL, Burek JD. A disease of freshwater fishes caused by Tetrahymena corliss Thompson, 1955, and a key for identification of holotrich ciliates of freshwater fishes. J Parasitol. 1975;6:217-

55. Johnson SK. Tet diseases of tropical fishes and an evaluation of correction techniques. Fish Disease Diagnostic Laboratory F12, Texas A \& M University, Austin. 1978.

56. Kazubski SL. Trichia lubomirskii (Helicidae), a new host of Tetrahymena limacis (Warren, 1932) Kozloff, 1946 (Ciliata) and Zonitoides nitidus Mull. (Zonitidae), a new host of T. rostrata (Kahl, 1926) Corliss, 1952, in Poland. Bull Acad Polonaise Sci. 1958;6:247-52.

57. Kim JH, Hayward CJ, Joh SJ, Heo GJ. Parasitic infections in live freshwater tropical fishes imported to Korea. Dis Aquat Organ. 2002;52:169-

58. Kozloff EN. The morphology and systematic position of a holotrichous ciliate parasitizing Deroceras agreste(L.). J. Morph. 1946;79:445-65

59. Kozloff EN. A comparison of the parasitic phase of Tetrahymena limacis (Warren) with clones in culture, with particular reference to variability in the number of primary ciliary meridians. J Protozool. 1956a;3:20-

60. Kozloff EN. Tetrahymena limacis from the pulmonate gastropods Monadenia fidelis and Prophysaon andersoni. J Protozool. 1956b;3:204-

61. Kozloff EN. A species of Tetrahymena parasitic in the renal organ of the slug Derocercas reticidatum. J Protozool. 1957;4:75-

62. Laird M. Parasites of Singapore mosquitoes, with particular reference to the significance of larval epibionts as an index of habitat pollution. Ecology. 1959;40:206-

63. Laoprasert T, Khaisri C, Chinabut S. Study on white ulcerative disease in guppy (Poecilia reticulata). Proceeding of the Seminar on Fisheries 2001. The Aquatic Animal Health Research Institute (AAHRI) newsletter, abstracts from Volume 10 No.2. Bangkok, Thailand. 2001.

64. Lynn DH, Molloy D, LeBrun R. Tetrahymena rotunda sp. (Hymenostomatida: Tetrahymenidae), a ciliate parasite of the hemolymph of Simulium (Diptera: Simuliidae). Trans Am Microsc Soc. 1981;134-141.

65. Michelson EH. Distribution and pathogenicity of Tetrahymena limacis in the slug Deroceras reticulatum. Parasitology. 1971;62:125-

66. Ronquist F, Huelsenbeck J. MrBayes 3: Bayesian phylogenetic inference under mixed models. Bioinformatics. 2003;19:1572-1574.

67. Seaman GR, Tosney T, Berglund R, Goldberg G. Infectivity and recovery of Tetrahymena pyriformis strain S from adult female cockroaches (Periplaneta americana). J Protozool. 1972;19:644-

68. Stout JD. The ecology, life history and parasitism of Tetrahymena [Paraglaucoma] rostrata (Kahl) Corliss. J Protozool.1954;1:211-

69. Wakita K, Imai S, Hatai K. "Histopathological study on Tetrahymena infection in Dwarf Gourami (Colisa lalia)." 5th Symposium on Diseases in Asian Aquaculture. 2002.

70. Wang Q, Luo S, Ghonimy A, Chen Y, Guo Z, Liu H, Zhang D. Effect of dietary l-carnitine on growth performance and antioxidant response in Amur minnow (Phoxinus lagowskii Dybowskii). Aquacult Nutr. 2019;25:749-760.

71. Williams NE. The polymorphic life history of Tetrahymena patula. J Protozool. 1960; 7:10-

72. Wilson MJ, Coyne C, Glen DM. Low temperatures suppress growth of the ciliate parasite, Tetrahymena rostrata, and pathogenicity to field slugs, Deroceras reticulatum. Biocontrol. Sci. Techn. 1998;8:181- 
73. Wright JF. Tetrahymena pyriformis (Ehrenberg) and corlissi Thompson parasitic in stream dwelling triclads (Platyhelminthes: Turbellaria). J Parasitol. 1981;67:131-133.

74. Xue Z, Zhang Y, Lin M, Sun S, Gao W, Wang W. Effects of habitat fragmentation on the population genetic diversity of the Amur minnow (Phoxinus lagowskii), Mitochondrial DNA Part B 2017;2:331-336.

75. Lwoff, A. Infection experimentale a Glaucoma piriformis chez Qalleria mellonella (Lepidoptere). C.R. Acad Sci Paris. 1924;178:1106-

76. Windsor DA. Colpoda steinii and Tetrahymena limacis from terrestrial pulmonated gastropods collected in Illinois. (Abstr.) J Protozool. $1959 ; 6: 33$.

77. Janda V, JíRovEC O. Uber kunstlieh hervorgerufenen Parasitismus eines freilebenden Ciliaten Glaucoma piriformis und Infektionsversuch mit Euglena gracilis and Spirochaeta biftexa. Vestnik Ceskoslov. Zool. spolec. Praze. (Mem. Soc. zool. tchicosl.) 1937;5:34-

78. Corliss JO. 1951. Morphology and systematic status of pure culture strains in the Colpidium-Glaucoma-Leucophrys-Tetrahymena (Abstr.) Proc Amer Soc Protozool. 2:11.

\section{Tables}

Table 1. Morphological identification characteristics of parasitic Tetrahymena spp.

\begin{tabular}{|c|c|c|c|c|c|c|c|}
\hline Species & Size in vivo & Body shape & $\begin{array}{l}\text { Caudal } \\
\text { cilia }\end{array}$ & $\begin{array}{l}\text { SK } \\
\text { No. }\end{array}$ & $\begin{array}{l}\text { Mi } \\
\text { No. }\end{array}$ & $\begin{array}{l}\text { CVP No. \& } \\
\text { position }\end{array}$ & References \\
\hline T. corlissi & $\begin{array}{l}\text { an average } 52 \times 32 \\
\mu \mathrm{m}\end{array}$ & $\begin{array}{l}\text { elongate, pointed anteriorly and rounded } \\
\text { posteriorly }\end{array}$ & present & $\begin{array}{l}25- \\
31\end{array}$ & 1 & 2 or 3; SK6-10 & 16 \\
\hline $\begin{array}{l}\text { pyriformis } \\
\text { py. }\end{array}$ & ca. $50 \times 30 \mu \mathrm{m}$ & pear-shaped & absent & $\begin{array}{l}15- \\
25\end{array}$ & N/A & 2; SK5, 6 & 5 \\
\hline $\begin{array}{l}\text { T. } \\
\text { stegomyiae }\end{array}$ & $60-100 \mu \mathrm{m}$ & pear-shaped & absent & $\begin{array}{l}25- \\
30\end{array}$ & 1 & - & 1 \\
\hline $\begin{array}{l}\text { Thironomi } \\
\text { chir }\end{array}$ & ca. $40 \times 23 \mu \mathrm{m}$ & elongate & absent & $\begin{array}{l}23- \\
28\end{array}$ & 1 & 3; SK6-9 & 1 \\
\hline T. vorax & $<150 \mu \mathrm{m}$ & posterior end is drawn out into a tail & absent & $\begin{array}{l}18- \\
23\end{array}$ & 0 & 2-6; SK5-10 & 7 \\
\hline T. rostrata & $50-60 \times 30-40 \mu \mathrm{m}$ & Vary & present & $\begin{array}{l}36- \\
58\end{array}$ & 1 & 3 or 4 ; SK6-12 & 5,7 \\
\hline T. limacis & $40-55 \times 30-40 \mu \mathrm{m}$ & $\begin{array}{l}\text { Cucumber-shaped with strongly apiculate } \\
\text { anterior end }\end{array}$ & absent & $\begin{array}{l}26- \\
46\end{array}$ & 1 & 2 or $3 ; 5-8$ & 58 \\
\hline T. rotunda & $\begin{array}{l}40-90 \mu \mathrm{m} \text { (after } \\
\text { staining) }\end{array}$ & bluntly ovoid to globose & present & $\begin{array}{l}50- \\
66 ;\end{array}$ & -- & not observed & 64 \\
\hline T. papula & 80-100 $\mu \mathrm{m}$ & piriform, bag-shaped & absent & $\begin{array}{l}33- \\
45\end{array}$ & 1 & 2-6; SK9-16 & 78 \\
\hline
\end{tabular}

Table 2. Reports of parasitic Tetrahymena species and their hosts. 


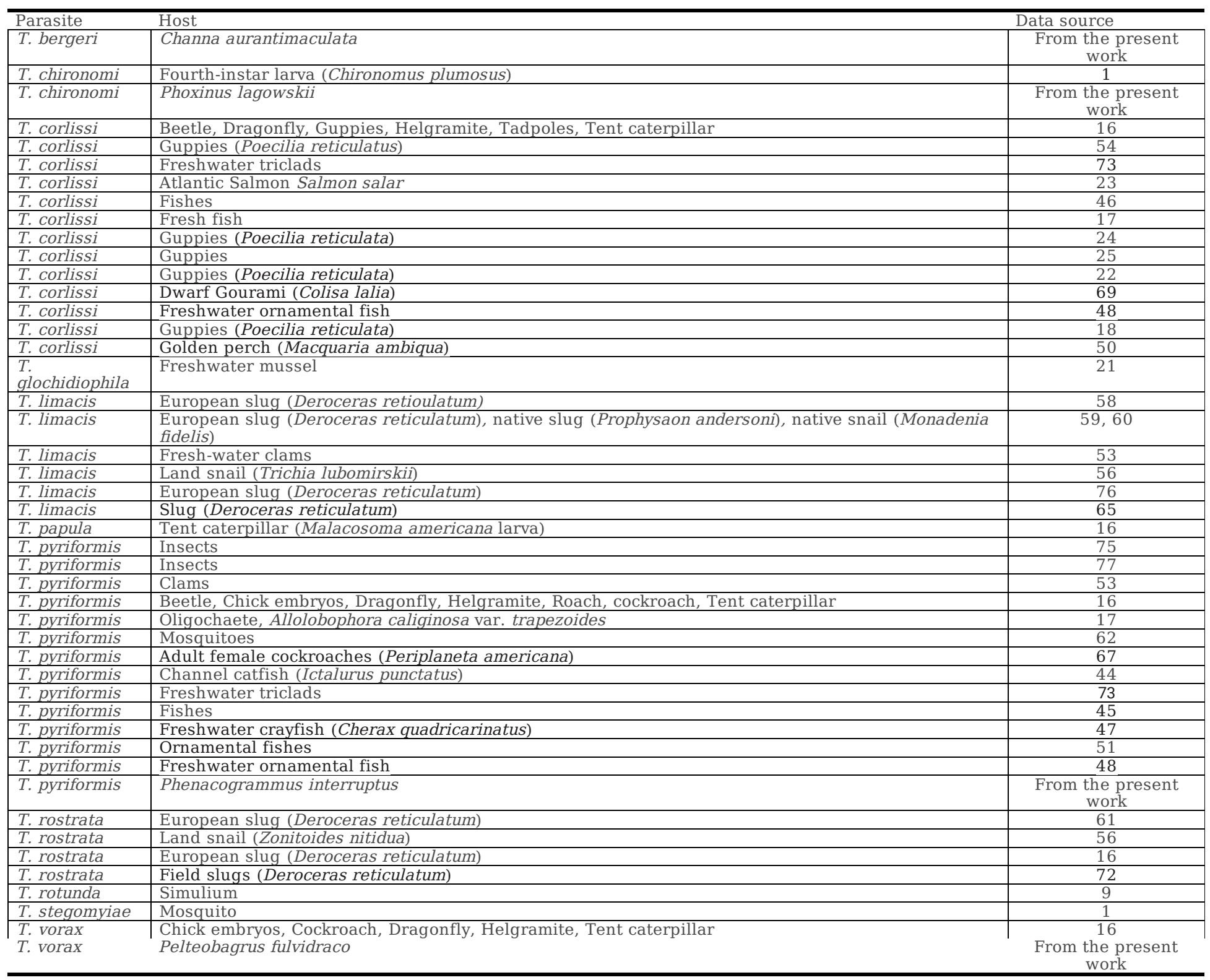

\section{Figures}



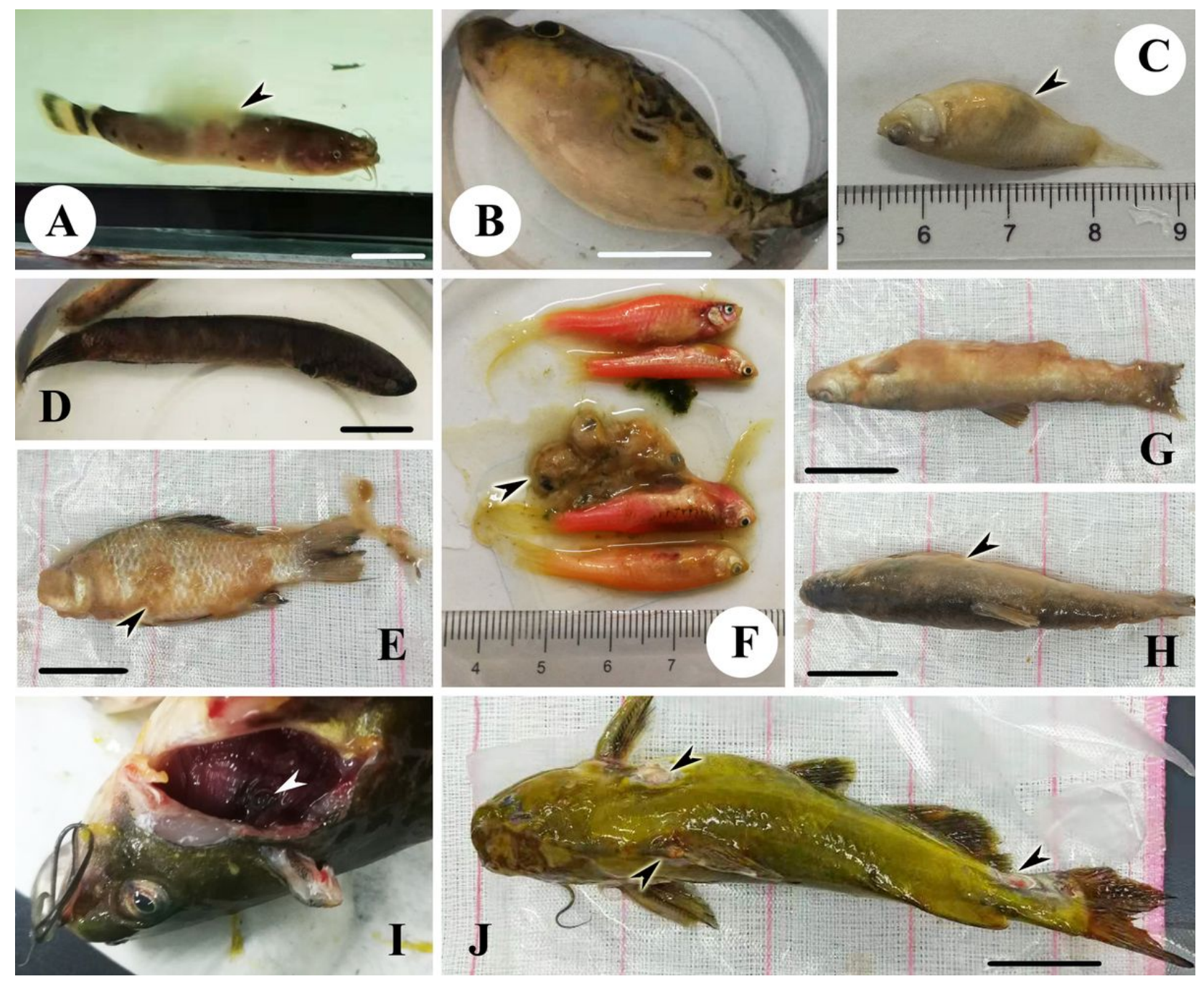

\section{Figure 1}

Diseased fishes isolated from farms or aquaculture markets of Harbin, northeastern China infected by Tetrahymena spp. A. Malapterurus electricus; B. Tetraodon palembangensis; C, Poecilia latipinna; D, Channa aurantimaculata; E, Carassius auratus; F, zebrafish; G, H, Phoxinus lagowskii; I. J. Pelteobagrus fulvidraco. Scale bars: A. $10 \mathrm{~cm}(A, D) ; 4 \mathrm{~cm}(B, E, G, H, J)$. 

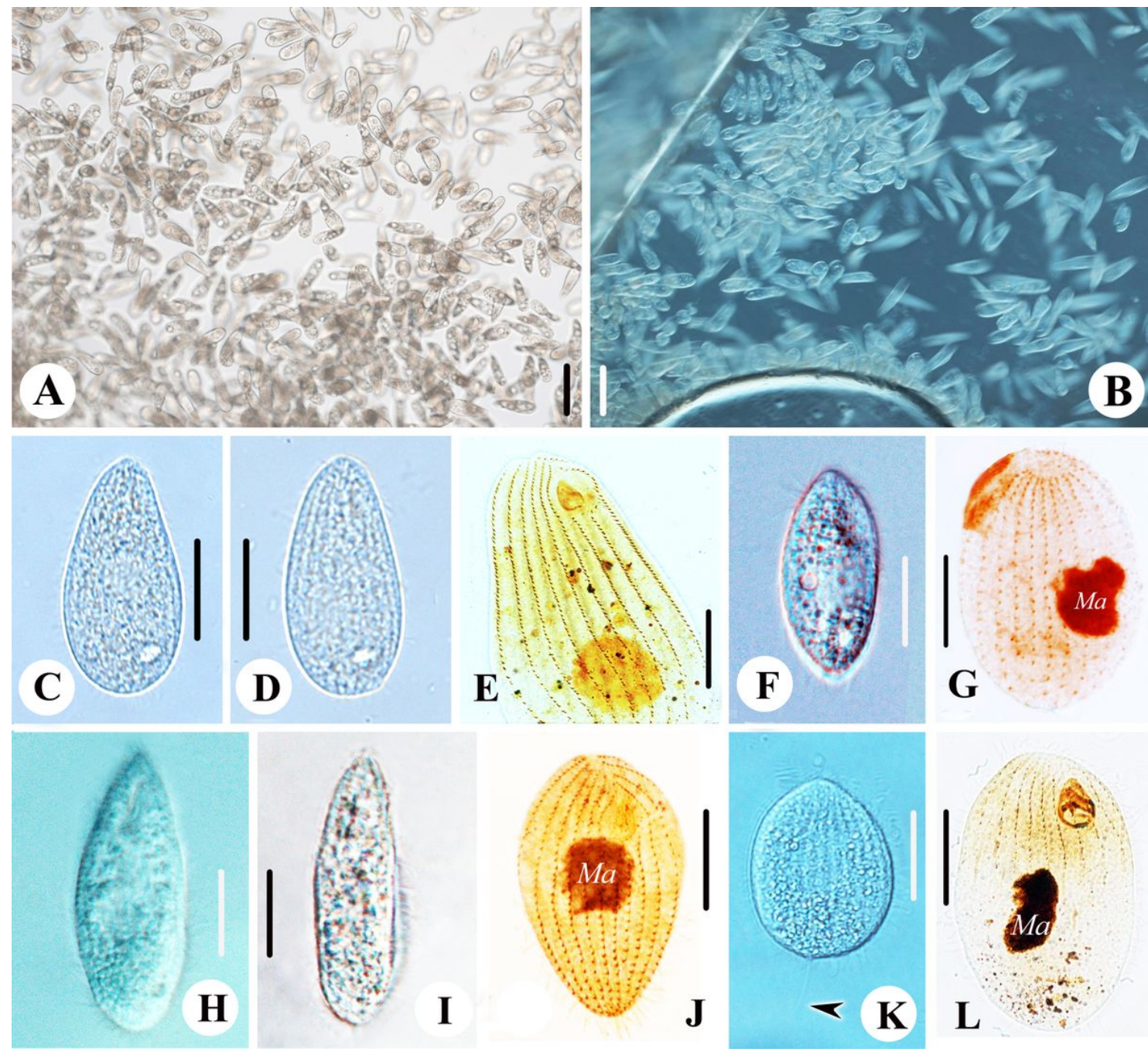

\section{Figure 2}

Photomicrographs of parasitic Tetrahymena species isolated from Harbin in vivo (A-D, F, H, K) and after silver carbonate staining (E, G, J, L). (A, B) Views of numerous parasitic Tetrahymena sp. in low magnification. (C-E) Tetrahymena pyriformis. $(F, G)$ Tetrahymena vorax. $(H-J)$ Tetrahymena chironomi. $(K, L)$ Tetrahymena bergeri, arrowhead shows caudal cilium. Scale bars: $100 \mu \mathrm{m}(\mathrm{A}, \mathrm{B}), 25 \mu \mathrm{m}(\mathrm{C}, \mathrm{D}, \mathrm{F}-\mathrm{L}), 10 \mu \mathrm{m}(\mathrm{E})$. 


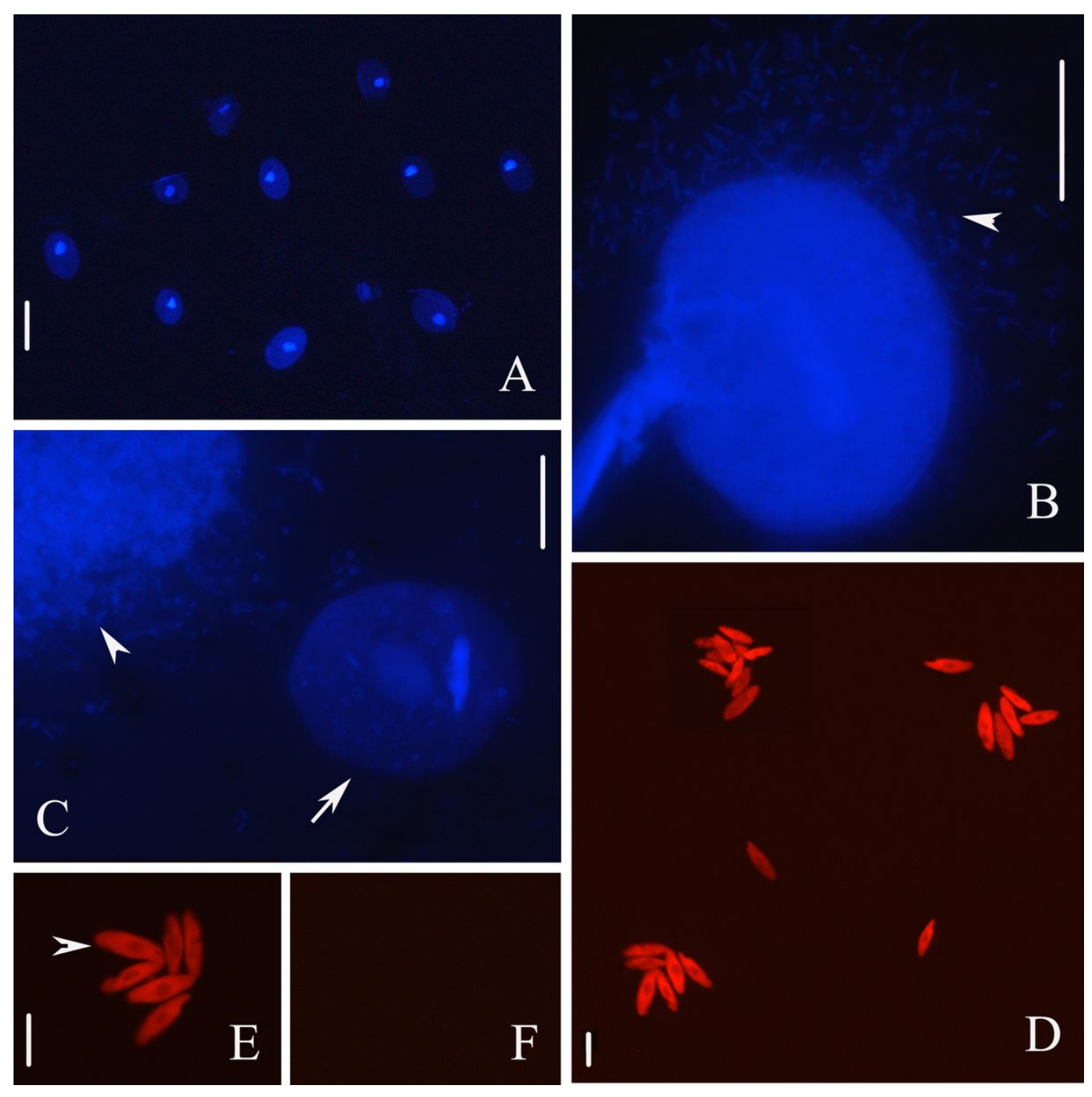

\section{Figure 3}

Simultaneous fluorescence in situ hybridization (FISH; D-F) and Hoechst33342 (A-C) staining of parasitic Tetrahymena species (FISH; A-D) and other test ciliates (F). (A) Views of numerous cells of parasitic Tetrahymena sp. in low magnification. (B) To show bacteria (arrowhead) around Tetrahymena sp. (C) To show the process that Tetrahymena sp. (arrow) eating tissue (arrowhead) as well as bacteria of host. (D, E) Presence of red fluorescence signals for T.

pyriformis, T. vorax, T. chironomi and T. bergeri (arrowhead, signals of four species were similar, so only that of T. pyriformis are showed). (F) Other test ciliates (not assigned to Tetrahymena) after simultaneous fluorescence in situ hybridization. Scale bars: $50 \mu \mathrm{m}(\mathrm{A}, \mathrm{D}, \mathrm{E}), 20 \mu \mathrm{m}(\mathrm{B}, \mathrm{C})$. 


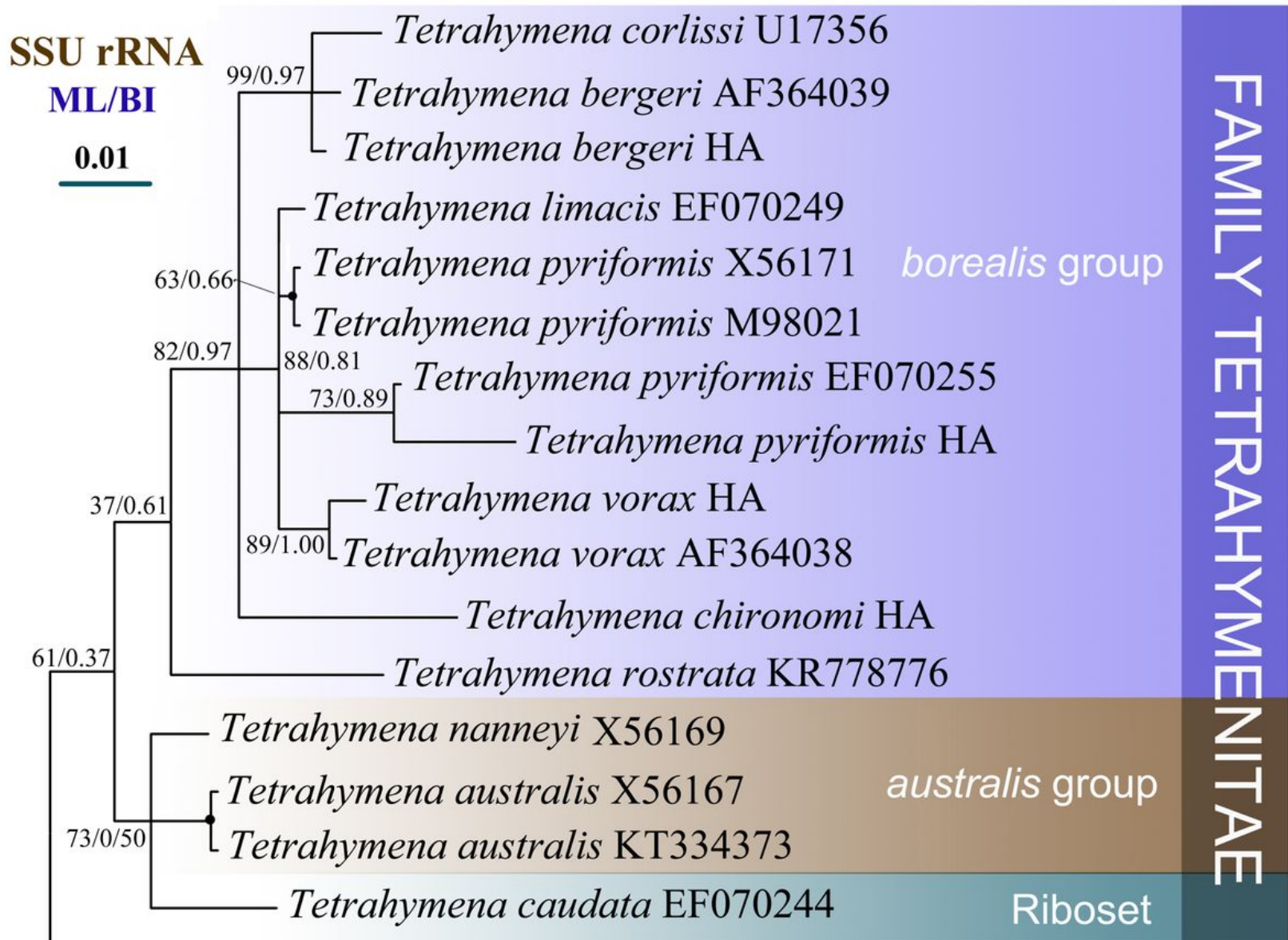

Glaucoma scintillans AJ511861 Glaucoma chattoni X56533

\section{Glaucomidae}

Figure 4

Maximum likelihood tree inferred from SSU rDNA sequences, showing the position of phylogentic relationship of parasitic Tetrahymena species. Numbers at nodes represent the bootstrap values of Maximum likelihood out of 1,000 replicates and the posterior probability of Bayesian Inference. Fully supported $(100 \% / 1.00)$ branches are marked with solid circles. The scale bar corresponds to one substitutions per 100 nucleotide positions. HA refers 'Harbin population'.

\section{Supplementary Files}

This is a list of supplementary files associated with this preprint. Click to download.

- GAJFP.jpg 